Альтернативный способ подделки карты путем анализа точного размера, положения и других свойств наночастиц с последующим созданием точной копии практически нереализуем из-за очень высокой сложности процесса.

Разработчики QSA утверждают, что, несмотря на кажущуюся сложность концепции, она легко и относительно недорого может быть реализована на практике с помощью доступных уже сегодня технологий.

Маловероятно, что всеобщее внедрение банками описанных выше систем дело ближайшего будущего. Финансовая индустрия достаточно консервативна, а массовое внедрение новых технологий - штука весьма затратная.

Кроме того, очень важно, чтобы все преимущества хитроумных решений не сводились на нет несовершенством внедрения, как это сейчас кое-где обстоит с чиповыми картами. Ведь в чем нынче основная проблема: если старинный банкомат или платежный терминал не может прочитать защищенный чип, то он довольствуется магнитной дорожкой, оставленной именно для совместимости со старым оборудованием. И вся защита идет насмарку [3].

$$
* * *
$$

1. Новостной портал "Вести.ру" Что ждет рынок кредитных карт в будущем? [Электронный ресурс] Режим доступа: - https://www.vesti.ru

2. Официальный сайт "MoneyMan" Что выбрать: кредитные карты или микрозаймы? [Электронный pecypc] - Режим доступа: - https://moneyman.ru

3. Официальный российский блог "Лаборатории Касперского" Квантовый пластик: какими будут кредитки будущего? [Электронный ресурс] - Режим доступа: - https://www.kaspersky.ru/blog/

\title{
Завершинская А.А. \\ Понятие тотального залога в Гражданском Кодексе Российской Федерации
}

Оренбургский государственный университет (Россия, Оренбург)

doi:10.18411/spc-20-01-2018-03

idsp: 000001:spc-20-01-2018-03

Не так давно в Российском законодательстве появилось такое понятие как «тотальный залог». Федеральным законом от 21 декабря 2013 года N 367-Ф3 "О внесении изменений в часть первую Гражданского кодекса Российской Федерации и признании утратившими силу отдельных законодательных актов (положений законодательных актов) Российской Федерации" была изменена статья 339 Гражданского кодекса Российской Федерации. Законодатель ввел в оборот новую составляющую залогового права, получившую свое название «тотальный залог». Изменение вступило в силу 1 января 2015 года.

Институт тотального залога появился в Гражданском кодексе Российской Федерации в результате реформы залогового права законодателем. Тотальный залог иными словами можно назвать залогом всего имущества, из-за этого толкования возникает множество вопросов относительно практики его реализации.

Тотальный залог, как составляющая залогового права, малоизучена на сегодняшний день, поскольку вошла в российское законодательство не так давно. Но всё же новелла стала предметом внимания для многих ученых-юристов.

Новая редакция Гражданского кодекса Российской Федерации, а именно статья 339 пункта 2, установила, что залогодатель, если он является субъектом предпринимательской деятельности, вправе описать любым способом предмет залога, позволяющим идентифицировать имущество в качестве залога на момент обращения взыскания, в том числе и на все имущество, либо часть имущества, либо залог имущества определенного рода и вида. 
На мой взгляд, негативным моментом является то, что данный вид залога может приобрести так называемый эффект «публичности», то есть эффект действия против третьих лиц, которые, возможно, знают о тотальном залоге или только могут знать о нем. Лица, договорившиеся о залоге, именуемые в Гражданском кодексе Российской Федерации как залогодатель и залогодержатель, могут обратиться за нотариальной помощью в случае, если они хотят внести соответствующую информацию в реестр. Институт реестра уведомлений о залоге появился в праве благодаря реформе Гражданского кодекса Российской Федерации. Ведут этот реестр нотариальные конторы, иначе говоря, нотариусы.

С информацией о залоге недвижимого имущества потенциальный покупатель может познакомиться в Едином государственном реестре прав на недвижимое имущество и сделок с ним. Однако в ЕГРН (Едином государственном реестре прав на недвижимое имущество и сделок с ним) отражаются только ограничения пользования недвижимым имуществом. Для публичности залога движимых вещей был создан отдельный реестр, получивший свое название как реестр уведомлений о залоге движимого имущества. Но основным условием является то, что обе стороны договора должны внести в реестр соответствующую информацию по имуществу.

Исходя из всего изложенного выше, возникает ряд вопросов, главный из которых: если в состав имущества, которое входит в тотальный залог, будет не только недвижимость, но и движимое имущество, а также будет официально сообщено в реестр уведомлений о залоге движимого имущества, что все имущество предпринимателя заложено, будет ли это основанием считать, что недвижимое имущество тоже заложено и не потребуется ли регистрация заложенного недвижимого имущества в ЕГРП? Скорее всего, все объекты, которые требуют обязательной идентификации, при регистрации не вошли в тотальный залог, то есть регистрация недвижимого имущества в ЕГРП все же потребуется. На мой взгляд, во избежание таких вопросов, в оформлении документов в реестрах должником, законодатель должен был указать, что заложено не просто все имущество, а добавить конкретики, то есть, что должником заложено все движимое имущество.

При составлении нововведений, законодатель должен предусматривать все возможные возникающие ситуации и вопросы при оформлении документов и внесении информации залогодателем и залогодержателем в реестры. На мой взгляд данные новеллы в законе немного недоработаны, поскольку им, как уже говорилось, не хватает конкретики и точности в трактовках информации относительно заложенного имущества.

Структура реестра залоговых уведомлений построена так, что искать информацию в реестре можно по двум критериям, то есть по двум идентификаторам:

- Объект залога;

- Название, то есть наименование, залогодателя.

Поиск по объекту, по своей сути, не даст никакого результата, потому что у тотального залога как такового объекта нет, то есть возможны случаи, когда все имущество лица уже заложено и поиск не имеет результатов. Исходя из этого, все заинтересованные лица будут искать информацию о залоге уже не по объекту, а по названию, то есть по идентификатору залогодателя. Из этого всего получается, что все лица, контактирующие с залогодателем, попадают под действие «тотального залога», а значит, они приобретают имущество, которое ограничено, то есть обременено залогом.

Теоретически тотальный залог уже имеет некоторые минусы, а как же он будет реализовываться на практике? В практической деятельности залог может найти свое, так называемое признание, при получении лицом банковского кредита. Данная схема позволит получить кредитору удовлетворение за счет любого имущества, имеющегося у заемщика на момент обращения взыскания. В этом случае договор будет содержать в себе такую информацию, как: «Залогом является все имущество, принадлежащее 
залогодателю на праве собственности на момент заключения настоящего договора». Тотальный залог в этой ситуации сможет снизить вероятность оспаривания залога со стороны недобросовестных должников.

Но у всего есть вторая сторона. Например, можно смоделировать такую ситуацию, в которой контрагентом залогодателя, заложившего все имущество, будет являться обычный гражданин. Допустим, что этот гражданин, в последующем покупатель, захотел приобрести автомобиль дорогостоящей марки. Компания, реализующая продажу автомобилей, заложила все свое имущество какому-либо банку, при этом внесла информацию в реестр залогов. Из всего вышеперечисленного получается, что покупатель, приходя за покупкой, приобретает автомобиль, обремененный залогом. В такой ситуации, если компания не сможет выполнить свои обязательства перед кредитором, банк, имея всю информацию о покупках авто, вполне может обратиться к покупателям с взысканием. Это еще один существенный недостаток тотального залога. Срабатывает эффект залога против третьих лиц, то есть публичности залога, он не ограничен рядом каких-либо определенных категорий которые должны были быть ограничены, например, как в приведенном мною случае с покупателем. Следует отметить, что во многих международных практиках помимо граждан-потребителей существуют и другие ограничения тотального залога: нанимателей жилья или же граждан-работников при банкротстве компаний.

Подводя итог, хотелось бы подчеркнуть по данному вопросу следующее: новеллы, вошедшие в Гражданский кодекс Российской Федерации, а именно конструкция тотального залога, имеет не только плюсы, но и минусы. Как уже было сказано, удобство залога в том, что кредитор может получить удовлетворение за счет любого имущества, находящегося у должника на момент обращения взыскания, тем самым кредитор снижает риски оспаривания залога со стороны недобросовестных должников. Тем не менее, у новшества есть некоторые недостатки. Законодатель должен скорректировать норму, а именно исключить такой принцип, как следование залога за вещью, в отношении некоторых категорий лиц, а именно гражданпотребителей, заключающих сделки с залогодателями. Особое внимание следует уделить формулировкам, в частности: «залог всего имущества». В данном случае возникает вопрос, входит ли недвижимое имущество в «залог всего имущества», а также и иные объекты, которые требуют обязательной идентификации, например, залог долей в обществе с ограниченной ответственностью или же залог исключительных прав.

$$
* * *
$$

1. "Гражданский кодекс Российской Федерации (часть первая)" от 30.11.1994 N 51-Ф3 (ред. от 29.12.2017).

2. Комментарии к статье 339 Гражданского Кодекса Российской Федерации.

\section{Карташов И.И., Городилина В.В. \\ К вопросу о соотношении понятий «правосудие» и «судебный контроль» В уголовном судопроизводстве}

Российский государственный университет правосудия (Россия, Воронеж)

doi:10.18411/spc-20-01-2018-04

idsp: 000001:spc-20-01-2018-04

Аннотация

В статье рассматриваются теоретические вопросы сущности и содержания деятельности суда по осуществлению правосудия и судебному контролю в рамках производства по уголовному делу. Делается вывод о наличии специфических 